are, however, very different, as the flavines, unlike the carotenes, contain nitrogen, are soluble in water, resist the action of acids and oxidising agents and are labile to alkalis. The flavines can act as enzymes when combined with complex carriers and also as biological hydrogen acceptors.

Dr. R. P. Linstead described the phthalocyanines, a new class of synthetic colouring matters related to the naturally-derived porphyrins. These may be prepared from ortho-cyanobenzamide by the action of metals at $250^{\circ} \mathrm{C}$., when they are formed as blue pigments containing metal (magnesium, iron, copper). Of these, only the magnesium compound is unstable to cold concentrated sulphuric acid, which removes the metal and yields the parent substance of the group, phthalocyanine. The metal-free, copper and magnesium pigments have the formulæ $\left(\mathrm{C}_{8} \mathrm{H}_{4} \mathrm{~N}_{2}\right)_{4} \mathrm{H}_{2}$, $\left(\mathrm{C}_{8} \mathrm{H}_{4} \mathrm{~N}_{2}\right)_{4} \mathrm{Cu}$ and $\left(\mathrm{C}_{8} \mathrm{H}_{4} \mathrm{~N}_{2}\right)_{4} \mathrm{Mg}$. $2 \mathrm{H}_{2} \mathrm{O}$ respectively. They can be purified and the properties determined. They are remarkably stable except to acid oxidising agents; the copper compound may even be sublimed in nitrogen at $580^{\circ} \mathrm{C}$.
Phthalocyanine differs from porphin, the structural basis of the porphyrins, in having four isoindole (benz-pyrrole) rings in place of four pyrroles. These are joined by nitrogen atoms $(-\mathrm{N}=)$ in place of the methine groups $(-\mathrm{CH}=)$ of the porphyrins and the whole forms a large, presumably planar, ring.

It was suggested by Dr. N. V. Sidgwick that the existence of the magnesium compound as a dihydrate is due to the inability of the metal to assume a planar 4-covalent state. If this is so, then beryllium, which can be neither planar 4-covalent nor hexavalent, should form no phthalocyanine pigment. Dr. K. F. Armstrong said that work which he has carried out in the porphyrin series gives somewhat analogous results in that certain zinc compounds appear to exist in a hydrated form.

In reply to a question by Prof. Freudenberg, Prof. R. Robinson stated his opinion that anthocyanins, flavines and substances of the tannin group are not capable of direct interconversion in the living plant but probably have a common natural precursor.

\title{
Early Bronze Age Site in the South-Eastern Fens
}

$\mathrm{S}^{\mathrm{p}}$ ECIAL interest is attached to a report on the investigation of an Early Bronze Age settlement site on Plantation Farm, Shippea Hill, seven miles east-north-east of Ely, which appears in the Antiquaries Journal, 13, No. 3. It is the firstfruits of the activities of the Fenland Research Committee, which was founded in 1932 under the presidency of Prof. A. C. Seward with the object of studying the fens, as an area affording opportunities unrivalled in Britain for investigating post-glacial changes of environment in relation to man. An essential feature in the Committee's scheme of research was to secure the co-operation of specialists in the different sciences. How far this has been carried out may be seen in the report under consideration, in which Mr. Grahame Clark is responsible for the account of the site and the archæological data, the investigation of the peat deposits and the analysis of the contained pollens has devolved on Dr. H. and Mrs. M. E. Godwin, Dr. W. A. Macfadyen reports on the foraminifera of the silts and clay, Dr. Wilfrid Jackson on animal remains and Mr. A. S. Kennard on the Mollusca.

The site, a sandhill, lies in flat black peat country reduced to agriculture only by the drainage of the seventeenth century. This country is traversed not only by modern dykes and communications, but also by the meandering 'roddons' - banks of light brown silt. Recent investigation has shown that these roddons are extinct watercourses, of which the silted up beds appear as banks, owing to the shrinkage of the adjacent peat. On Plantation Farm some of them are as much as $7 \mathrm{ft} .3 \mathrm{in}$. above the surface of the peat. The site under investigation was rather less than three feet above the present surface of the peat, but when the Little Ouse flowed along the course of the roddon, the upper peat, which now blankets all but the extreme top of the sandhills, must have covered the whole to a depth of 12-13 ft.

The results of the archæological investigation may be summarised briefly as follows. The main occupation of the sandhill began in the Early Bronze Age, when a few inches of the upper peat had already formed. A numerically insignificant group of flint instruments of Tardenoisian type, lying loose on the sand, pointed to an earlier occupation of brief duration, for which there is no indication of dating, apart from the fact that in boring through the lower peat a micro-flake was found at the base some $17 \frac{1}{2} \mathrm{ft}$. down, which, it may be suspected, belongs to the Tardenoisian group. This would point to a Late Boreal date. The significant pottery of the Early Bronze Age settlement is Beaker, some of it of the best period. An ill-fired buff-coloured ware is difficult to place, but cannot be long after the Beaker, as the occupation of the site was short. The stone implements form an assemblage conforming to what might be expected in the early phases of the bronze age. Scrapers are the predominant implement of the industry, and barbed and tanged arrow heads are the most usual. In the absence of the leaf arrow head, the polished axe and the narrow finely serrated flake, the industry differs essentially from that of neolithic camps.

The majority of the animal remains belong to domestic animals; wild animals are rare. The dog and horse are absent. Dr. Wilfrid Jackson reports that the animal remains closely resemble those from Woodhenge.

Borings were made with the object of ascertaining the history of the site. The basal deposit consists of sand. At one point the sand dips to form a flatbottomed hollow, $17 \mathrm{ft}$. below the present surface of the ground. Here the deposits consist of a lower peat with a maximum thickness of $7 \frac{1}{2} \mathrm{ft}$., overlaid by a continuous deposit of buttery clay, and overlying this an upper peat, of which the greater part has wasted away.

The pollen analyses by Dr. and Mrs. Godwin point to the lower peat beds being of Late Boreal age, the most noteworthy feature being a marked predominance of alder. Oak, lime, hazel, elm and birch are present, but correspondingly low in amount. In the lowest deposit, however, there is a striking difference. Pinus is 68 per cent, alder falls to 22 per cent, and hazel is 42 per cent. In the upper peat, now reduced to 40 inches thick with the lower 24 inches only undisturbed by cultivation, there is a marked change. 
All the same trees are present, but there is no marked predominance of the alder. The transition through the bed from an early dominance of oak to a dominance of alder suggests increasing wetness and an increasing prevalence of alder swamp. This is borne out by the pollen of herbaceous plants which are aquatic in character. At the bronze age occupation level Titia has a maximum of 15 , an unusually high figure for post-glacial peats; but the occurrence of a similar high percentage elsewhere in the Fens suggests that Tilia may afford a valuable chronological index for the Fens as a whole. The Early Bronze Age settlement thus falls in the sub-Boreal period.

Combining the evidence from the reports on the Foraminifera by Dr. Macfadyen and on the freshwater Mollusca by Mr. A. S. Kennard, there would appear to have been certain changes in elevation in the history of the site. The point at which the Tardenoisian implement was found by boring in the lower peat now lies at $-22 \frac{1}{2} \mathrm{ft}$. O.D. Consequently at the date of that occupation the site must have been at a considerably higher elevation in relation to the sea than it is at present. A channel was at that time eroded through the peat and this was afterwards drowned by tidal estuarine silts of semi-marine character during a depression of the land in Atlantic times. A re-elevation took place, during which a channel, now $15 \mathrm{ft}$. below O.D., was eroded. This cuts into the marine silts and contains fresh-water Mollusca and the scales and bones of pike, pointing to a deep fresh-water river. The minor maximum of aquatic plants found to occur between two inches and nine inches from the base of the upper peat supplies a direct motive for the Early Bronze Age occupation in the shape of a dry 'island' situate in a shallow peat forming swamp. After a temporary recession, wet conditions set in again and ultimately caused the whole neighbourhood to be covered thickly with peat.

\section{Annual Conference of the Association of Special Libraries and Information Bureaux}

$\mathrm{T}$ HE tenth Annual Conference of the Association of Special Libraries and Information Bureaux was held at Wills Hall, Bristol, on September 22-25. The report presented to the annual meeting indicated that despite the admirable work the Association is doing, there have been decreases during the year both in membership and in income. The Council is arranging for an intensive new membership campaign and the decision to hold the meeting at Bristol was part of a definite attempt to break new ground.

One of the features of the programme was a symposium on the Saturday morning devoted to the preparation and production of information bulletins, house journals and reports. The first paper presented to this symposium, by Mr. J. C. Stopani Stuart, of Messrs. Armstrong Whitworth and Co. Ltd., gave a broad survey of the general methods of organising a research or information bureau, but with this exception the papers might be regarded as falling into two groups : those dealing with the collection of material and those concerned with its reproduction. The first group of papers contained contributions from representatives of the British Non-Ferrous Metals Research Association, the British Cast Iron Research Association, the Mond Nickel Co. Ltd., Messrs. Edgar Allen and Co. Ltd. and the Metropolitan-Vickers Electrical Co. Litd., and the detail with which the methods employed for the collection, selection and circulation of material used in the various abstract publications or information bulletins of these various organisations were described made the discussion of the utmost value to those engaged in such work. It is beyond question that the Association of Special Libraries and Information Bureaux provides in its annual Conference an unrivalled opportunity for comparing technique and discussing both general and special problems in this field.

The second group of papers, represented by those of Mr. G. T. Clarkson, of the Royal Aircraft Establishment, on the preparation and reproduction of illustrations for technical reports and of Mr. Norman Parley on facsimile processes with special reference to tabular work, were concerned with a special aspect of the same problem on which information is not so freely accessible as might be desired. Together these two papers contain much highly technical information as well as comparisons of different methods of reproduction available for tables and for illustrations which should have a wide range of utility. The service would be the greater if the Association could follow up the papers by compiling and issuing standard figures for the comparative costs of reproduction by different processes, having regard to the number of copies, type of finish and degree of permanence required.

This symposium was followed by a discussion on abstracting methods with particular reference to efficiency and economy. The discussion arose from a paper by Prof. J. C. Philip in which he gave a succinct account of the recent policy of the Bureau of Chemical Abstracts and emphasised the importance of developing co-operation between the various bureaux concerned with abstracting if the available resources are to be adequate for the task. As an example, Prof. Philip referred to relations which are being developed with the Bureau of Animal Nutrition. Possibilities with regard to the utilisation of the same abstracts for different purposes by several bureaux or abstract journals are obvious to the independent observer, and the practical difficulties which exist are not sufficiently great to stand in the way of the advantages to be reaped by co-operation. Even within the fields of a single science such as chemistry, however, individual societies like the Society of Public Analysts persist in duplicating the work of the abstracting bureaux, apparently through the mistaken belief that an abstract should not be a pointer to the paper but provide in itself detail for experimental work. Only the really wealthy can afford to indulge in such a policy with any efficiency.

Apart from these discussions, the programme contained other specialist contributions such as that of Mr. S. W. Gibson on the classification of subject titles for engineering periodicals, in which he urged the advantage of some measure of control in the titles of papers in this field such as could be supplied by the use of an agreed guide. Mr. Evans Lewin indicated the need for co-ordination in bibliographical work within the British Empire, while Mr. B. M. Headicar described recent developments in equipment.

One of the most interesting sessions, however, was that at which Sir John Russell, under the title 